\title{
Ethiopian Women Economic Empowerment Through Microfinance
}

\author{
Belay Mengstie \\ $\mathrm{PhD}$ Student \\ Punjabi University, India \\ E-mail: belaybelay40@gmail.com \\ Amanpreet Singh $P h D$ \\ Assistant Professor \\ Punjabi University, India \\ E-mail: amanpreet@pbi.ac.in
}

Received: July I3, 2020

Accepted: July 29, 2020

Online Published: August I5, 2020

doi: I0.4628I/ijfb.v4i2.708

URL: https://doi.org/I0.4628I/ijfb.v4i2.708

\begin{abstract}
Women's economic empowerment a strategy helping women to participate in the process of making decisions, supporting income increment, asset possession. The main aim of this study is to investigate the microfinance impact on women economic empowerment considering age and education as moderators. Data for this study have been collected from 346 respondents of microfinance beneficiary women. For data analysis multiple regression and moderated regression with Hayes (2018) process macro software were used in the study. Regression results showed that credit amount, age, number of training, marital status, education level, have a significant impact on the development of women's economy. However, the business experience has an insignificant impact on the development of women's economy. Moderated regression results revealed that age and education did not have a moderation role in the relationship between microfinance service and on the economic empowerment of women. Microfinance affects women's economic empowerment by improving women's independent income, increasing asset possession levels, and improved monthly saving amount. Moreover, the study proved that the microfinance institution has a vital role in women entrepreneurs' development and business exposure.
\end{abstract}

Keywords: Microfinance, Women Economic Empowerment, Moderating Effect.

\section{Introduction}

Microfinance institutions considered an important development program in Ethiopia for the last twenty years. The legal foundation for the microfinance movement and expansion in Ethiopia was started after the 1996 proclamation. In the development of microfinance, this proclamation considered a benchmark to start and develop microfinance in the country. Women's participation in microfinance is growing gradually though all microfinance industry has a shared vision of poverty alleviation and women economic development.

According to Yousuf and Dawit (2014) and Rahman, Khanam, and Nghiem (2017) study, Microfinance institutions are effective instruments providing basic services like saving, microcredit, and training. Microfinance institutions are important economic development agent intended to benefit women and lower-income people (Duflo, 2012). Microfinance institution has a great role in alleviating women the economic problem, creating self-employment opportunities, developing businesses for female entrepreneurs. Different studies reported women's benefits from the microfinance institution, participation leads to economic freedom, and business practices improvement (Addai, 2017; Belay \& Amanpreet, 2019). However, Women's involvement in economic activities is very low in Ethiopia (Yousuf \& Dawit, 20I4; Wassie, Kusakari, \& Sumimoto, 2019).

Economic empowerment improves women's opportunity for resources and non-financial resources. Moreover, it creates a good opportunity for skill development and market information (Alshebami \& Khandare, 20I5; Addai, 2017). The economic participation of Women is base to exercise their right and helping them to improve decision making roles over their household and in the community. According to Wanjiku and Nijiru (2016) study, Women's economic empowerment is creating equitable societies.

There are controversies on the impact of microfinance economic development of women clients. Odell (2010) study identified the problem of generalization taking into consideration the difference between microfinance programs. Stewart, Van Rooyen, Dickson, Majoro, and de Wet (2010) study in Africa found little impact of Microfinance on the income of beneficiaries. According to Rathiranee \& Semasinghe (20I5) study, microfinance service proved a positive impact on women's income increment in Sri Lanka. Addai (2017) and Rahman el al. (2017) study indicated that microfinance 
affects the economy of women in Ghana and Bangladesh respectively. Different researchers confirmed the significant effect of microfinance (Kato \& Kratzer, 2013; Swapna, 2017; Sell \& Minot, 2018).

The main objective of this research is to analyze Ethiopian women's economic empowerment through microfinance by considering the moderating effect of age and education. We aim to deepen recent research, by considering economic empowerment through microfinance. Moreover, the moderating effect of age and education are investigated deeply.

\section{Microfinance and Women Economic Empowerment}

Microcredit services are considered a society based strategy to give different finance-related resources for the poor and disadvantaged society to enhance the lives of clients (Sinha, 2006). The microfinance sector supports the community in its transition towards the country's development and peace and building. According to Rahman et al. (2017), the microfinance industry supports local economic development by providing the needed financial and non-financial services for small enterprise development. Some researchers consider microfinance as a survival strategy in a time of disaster and sustainable peace development (Yousuf \& Dawit, 2014; Khanday, Shah, Mir, \& Rasool, 2015; Sell \& Minot, 2018).

In Ethiopia context, supervision and Licensing Microfinance Proclamation No. 626/2009 define microfinance as "financial services providers including credit, savings, drawing, transferring money, and related services." This microfinance business definition does not confine the microfinance institution to only credit. In this article Microfinance considered as finance-related services provision to poor people and small enterprises that lack financial institution service. Microfinance is not limited to borrowing activities but also includes savings, transfer facilities, training, insurance, and others. The microfinance sector supports women financially by providing seed money and supports women to get constant income to their families (Tandon, 2016; Rashid, John, Consolatta, \& Stephen, 2015). According to Gundappa (2014), many Women were clients of microfinance in different countries. Women's economic development generated self-esteem and respect for women microfinance beneficiaries (Khanday et al., 2015). Microfinance provides finance to women who helped them to start or expand the business. Microfinance institution service of credit and training gives women confidence and a participating role in society and household decisions.

Microfinance institutions create self-employment opportunities, improving labor productivity, and increasing wage rates (Wanjiku \& Njiru, 2016). Microfinance impact mostly measured using variation in independent income, employment rate, and household consumption on a sustained basis. Microfinance institution service impact could also be directly known by considering increment in outcomes such as literacy rate, fertility rate, and housing pattern, and other related factors.

Microfinance helps to protect from different risks and diversify the business to increase sources of income as a vital instrument for women's economic development (Littlefield, Morduch, \& Hashemi, 2003; Addai, 2017). Many researchers' results showed that income played a significant role in consumption, capital formation, and other indicators of human wellbeing. When the income level increases access to balanced food, access to medical services, and children's education are positively affected (Hussain, Mahmood, \& Scott, 2019; Wassie et al., 2019). Moreover, microfinance institutions provide services that seek to minimize the risk from adverse effects for the poor society. For example, savings programs are operating to help microfinance institution clients to gradually accumulate working capital for the times of crises and when there is capital need for different purposes. Efficient microfinance services decrease the unemployment rate, sources of income diversification. The economic empowerment of women could be achieved as a result of microfinance service.

\section{I Conceptual Framework}

Based on the evidence available in the literature conceptual framework was developed. More than thirty articles reviewed to develop this framework of the research.

According to (Sinha, 2006), assessing the impact of microfinance will be helpful for the betterment of services. Ledgerwood (1999) divides the impact of microfinance into three categories namely economic, socio-political, and personal. Economic empowerment may be influenced by both women's demographic characteristics and access to financial resources from microfinance institutions. The result expected is empowering economically which is manifested through ownership in income-generating activities, ownership of assets, increased income, savings, and decision making (Naeem, Khan, ul Hassan, \& Muhammad, 2018; Selvaraj, 2016).

Microfinance service (access to credit and training) and demographic variables (age and education) leads to women's economic empowerment. Addai (2017) study clearly showed that microcredits have an impact on women's economic developments but the relationship mainly takes into account education and. according to Rehman, Moazzam, and Ansari (20I5), research finding education and age affect the economic development of women beneficiaries. The main independent variables which microfinance institution provides are access to credit and training. According to Yousuf and Dawit (2014) and Rehman et al. (2015) finding women's involvement in business raises women's independent incomes and savings, increases their family monthly income, and other household resources which are the basis for women's economic empowerment.

\section{Data and Methodology}

We conducted this research in Ethiopia in the year 2019. From the literature review, 35 items that would women income, asset, saving, and decision making, credit, training was identified. The questionnaire was used to collect data from samples 
of 346 microfinance client respondents. The questionnaire focused on demographic characteristics, economic empowerment, and microfinance service.

The researcher takes 3 zone administrations from the Amhara regional state of Ethiopia. Based on the proportion of clients sample respondents were selected in each town administrations. Finally, by using simple random sampling respondents were selected. As a result, $51.5 \%$ of the respondents were from Dessie town administrations. $27 \%$ of the respondents were from the Debrebirhan town administration. The remaining $21.5 \%$ were from Woldia town administrations.

Regression data analysis technique was employed to examine independent variables: age, education, marital status, business experience, training, amount of credit that has a positive effect on the economic empowerment of women. Moreover, Moderated regression with Hayes process macro software (Hayes, 2018) was used to examine the moderating effect that age and education may have upon women's economic empowerment and microfinance. The econometrics model used is:

$\mathrm{CEEI}=\beta 0+\beta \mathrm{I}($ Age $)+\beta 2($ Marital $)+\beta 3($ Education $)+\beta 4($ experience $)+\beta 5($ Training $)+\beta 6($ Credit $)+\dot{\varepsilon}$

For measuring the economic empowerment of women, a Cumulative Economic Empowerment Index (CEEI) was used as a dependent variable it is developed by commuting up the individuals' scores obtained from asset, income, saving, control over the resource. Other researchers (Parveen \& Leonhauser, 2004; Parveen \& Chaudhury, 2009; Kaur, 2012;

Samad, 20I4; Yousuf \& Dawit, 20I4; Mohapatra, \& Sahoo, 2016) also used similar methods to measure women economic empowerment by developing a cumulative women economic empowerment index.

For moderated regression, the following model was used.

$$
\begin{aligned}
& \mathrm{EE}=\beta 0+\beta \mathrm{I}(\mathrm{MF})+\beta 2(\text { Age })+\beta 3(\mathrm{MFx} \text { Age })+\varepsilon \varepsilon^{\prime} \ldots \ldots \ldots \ldots \ldots . \ldots \text { age as moderator } \\
& \mathrm{EE}=\beta 0+\beta \mathrm{I}(\mathrm{MF})+\beta 2(\text { Education })+\beta 3(\mathrm{MFx} \text { Education })+\varepsilon \dot{\varepsilon} \ldots \ldots \ldots \text { education as moderator }
\end{aligned}
$$

The proxy variable for microfinance service is credit amount and for economic empowerment is total asset including cash.

\section{Results and Discussions}

This section of the study was conducted to contribute new information about the impact of microfinance on women's economic empowerment. Multiple regression and moderated regression were employed for data analysis.

\section{I Assumptions of Multiple Regressions}

\section{I.I Test of Normality}

The regression model assumption is based on variables of normal distributions. For this research, the histogram was checked and the result indicates that data used in the study is normally distributed.

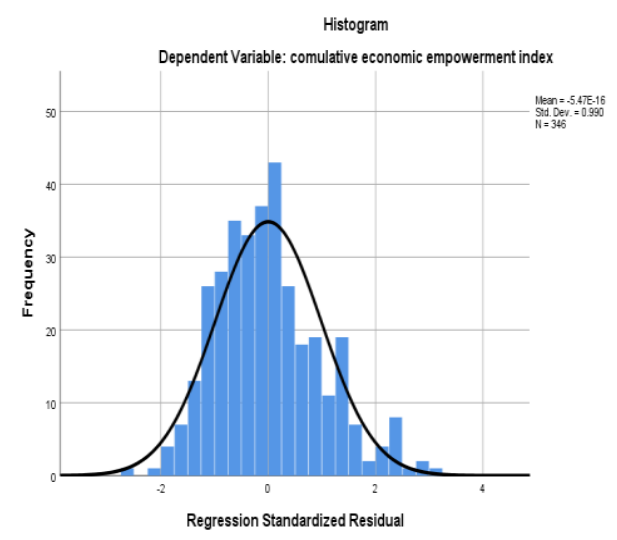

Figure I. Normality test using histogram

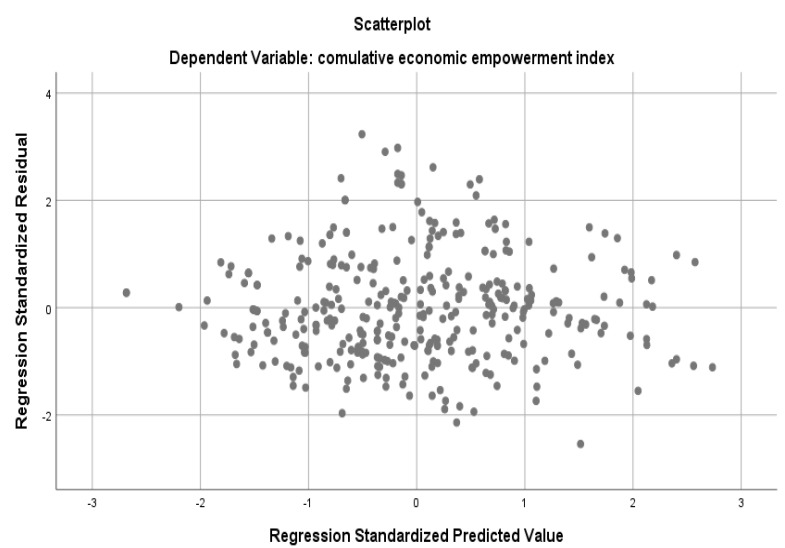

Figure 2. Linearity test

\subsubsection{Test of Linearity}

Multiple regressions assume linearity. This assumption was tested by using a scatter plot and the result of the test indicated that there is a linear relationship between microfinance service and women's economic empowerment. As depicted in the figure above (figure 2), it can be noted that all observations do lie on the straight line of the graphs. 


\subsubsection{Test of Multicollinearity}

Multicollinearity occurs when independent variables correlated highly (usually above $r=0.9$ ). The existence of multicollinearity can be diagnosed by analyzing the values of tolerance and Variance Inflation Factors. A tolerance of $<$ 0.10 and a VIF>IO shows that there is a multicollinearity problem. The result from the regression analysis of this current study (see table I below) VIF and tolerance are indicating that there is no multicollinearity problem.

Table I. Multicollinearity test

\begin{tabular}{lll}
\hline \multirow{2}{*}{ Variables } & \multicolumn{2}{l}{ Collinearity Statistics } \\
\cline { 2 - 3 } & Tolerance & VIF \\
\hline Age & .737 & $\mathrm{I} .357$ \\
\hline Marital status & .675 & $\mathrm{I} .48 \mathrm{I}$ \\
\hline Education & $.78 \mathrm{I}$ & $\mathrm{I} .280$ \\
\hline Business experience & .669 & $\mathrm{I} .495$ \\
\hline Number training & .822 & $\mathrm{I} .2 \mathrm{I} 7$ \\
\hline Amount of credit & $.75 \mathrm{I}$ & $\mathrm{I} .332$ \\
\hline
\end{tabular}

Table 2. Independence test result

\begin{tabular}{ccccc}
\hline \multicolumn{5}{c}{ Model Summary $^{\mathrm{b}}$} \\
\hline $\mathrm{R}$ & $\mathrm{R}$ & $\begin{array}{c}\text { Adjusted } \\
\text { Square }\end{array}$ & $\begin{array}{c}\text { Std. Error } \\
\text { of the } \\
\text { Estimate }\end{array}$ & $\begin{array}{c}\text { Durbin- } \\
\text { Watson }\end{array}$ \\
\hline $.616^{\mathrm{a}}$ & .380 & .367 & 6.17635 & 1.677 \\
\hline
\end{tabular}

\subsubsection{Independence of Error}

Independence of error assumes that the behavior of one participant should not affect the behavior of a participant. Table 2 above shows the results of the test of independence of errors. Durbin Watson statistic is used to test the independence of error. An acceptable range is from I.5 to 2.50. The results in Table shown above that the Durbin Watson statistic is I.677 which falls under acceptable range.

\subsubsection{Homoscedasticity}

The residuals at each level of the independent variables must be the same variance, if unequal this is called heteroscedasticity. Levene's test is used to check the homoscedasticity assumption. Therefore, the assumption homogeneity of variances has been fulfilled (see table 3).

Table 3. Test for homogeneity

\begin{tabular}{|c|c|c|c|c|c|}
\hline \multicolumn{6}{|c|}{ Test of Homogeneity of Variance } \\
\hline & & $\begin{array}{l}\text { Levene } \\
\text { Statistic }\end{array}$ & dfI & $\mathrm{df2}$ & Sig. \\
\hline \multirow{4}{*}{$\begin{array}{l}\text { Cumulative economic } \\
\text { empowerment index }\end{array}$} & Based on Mean & 1.475 & 7 & 338 & .175 \\
\hline & Based on Median & I.I06 & 7 & 338 & .359 \\
\hline & Based on Median & I.I06 & 7 & 316.121 & .359 \\
\hline & Based on trimmed mean & $\mathrm{I} .53 \mathrm{I}$ & 7 & 338 & .156 \\
\hline
\end{tabular}

\subsection{Regression Result}

Table 4. Regression result

\begin{tabular}{|c|c|c|c|c|c|}
\hline \multicolumn{6}{|c|}{ Coefficients $^{a}$} \\
\hline \multirow[t]{2}{*}{ Model } & \multicolumn{2}{|c|}{ Unstandardized Coefficients } & \multirow{2}{*}{$\begin{array}{c}\begin{array}{c}\text { Standardized } \\
\text { Coefficients }\end{array} \\
\text { Beta }\end{array}$} & \multirow[t]{2}{*}{$\mathrm{t}$} & \multirow[t]{2}{*}{ Sig. } \\
\hline & B & Std. Error & & & \\
\hline (Constant) & $4.4 \mathrm{I} 2$ & 1.320 & & 3.342 & .001 \\
\hline age & 1.330 & .228 & .285 & 5.835 & .000 \\
\hline Marital status & I.94I & .704 & .125 & 2.759 & .006 \\
\hline education & 1.394 & .249 & .260 & 5.598 & .000 \\
\hline business experience & .200 & .160 & .064 & 1.252 & .212 \\
\hline credit amount & .698 & .153 & .225 & 4.573 & .000 \\
\hline Training number & 1.354 & .285 & .224 & 4.757 & .000 \\
\hline
\end{tabular}


The result of regression in above table shows that that age of women $(p=0.00)$; marital status $(p=0.006)$, education $(\mathrm{p}=0.00)$; training $(\mathrm{p}=.00)$; credit amount $(\mathrm{p}=0.00)$, are significant independent variables that impact women economic. Business experience $(\mathrm{p}=0.2 \mathrm{I} 2)$ variable was insignificant predicator on economic development of women.

The result of this study showed that age plays a significant effect on women's development economically. Most women got better exposure to business and skill about different household and economic matters, as women age increased (Yousuf \& Dawit, 20I4). Business and skill experience helped them a better decision about their households, and in a society which leads them better economic position and empowerment. A similar result was found by Rehman et al. (2015) study that age played a significant role in women's economic empowerment. In Burma, a field study was conducted and the result of the study clearly shows that age affects positively women's economic empowerment (Ringkvist, 20I3).

Marital status has a vital role in women's economic empowerment. Most Married women economically empowered than divorced or single women. According to Addai (2017) findings, most married women have got support from their husbands and children which are important for women's economic empowerment. However, Yousuf and Dawit (20I4) finding shows that marital status has got as such a significant impact on the development of women economically.

The result of the study showed that educated were better on efficient usage of training and credit service and achieve economic empowerment. Moreover, educated women microfinance clients were proved to have a significant effect on improving the economic position of women. Women's level of education has a direct relationship with control over resources. Moreover, women's education affects her decision on contraception, better employment opportunity, and income which are the basic indicator of women's economic development and empowerment.

Training and credit have a significant impact on female empowerment economically. As the amount of credit amount increased, the use of credit for income-generating activities increased. Training attended women more likely to enhance business skills and knowledge than women did not attend training. The number of training significantly affects the economic empowerment of women. Most of the respondents reported that all members of microfinance participated in training before they got credit (Parveen \& Leonhauser, 2004; Korkmaz, Goksuluk, \& Zararsiz, 20I4).

\subsection{Moderated Regression Result}

To examine the moderated effect of age and education, moderated regression with Hayes (2018) process macro software was employed. Hayes's process macro result indicated that age has no moderation effect on the relationship between microfinance service and women entrepreneurship in the study area (see table 5). Research conducted by Addai (2017) in Ghana shows that microfinance has a positive effect on women's economic development, but such a relationship is dependent on the age and education level of the women.

Table 5. Hayes process macro result age as a moderator

\begin{tabular}{|c|c|c|c|c|c|c|}
\hline \multicolumn{7}{|l|}{ Model } \\
\hline coeff & se & $\mathrm{t}$ & $\mathrm{p}$ & \multicolumn{3}{|c|}{ LLCIULCI } \\
\hline constant & 377397.811 & 16178.608 & 23.327 & .000 & 345575.704 & 409219.918 \\
\hline microfin & 1.419 & .219 & 6.489 & .000 & .989 & 1.849 \\
\hline Age & 12072.198 & 1945.598 & 6.205 & .000 & 8245.354 & 15899.043 \\
\hline Int_1 & .042 & .030 & 1.398 & .163 & -.017 & .102 \\
\hline
\end{tabular}

Based on table 6 below the moderating effect of education on relationship microfinance service and women entrepreneurship is insignificant. The result of the study is different from former researchers like Laha and Kuri (20I4). Their study only focused on merely establishing the relationship between microfinance service and women's economic status paying attention to other women's economic development attributes such as age and educational background which affect the relationship existing between microfinance service and women entrepreneurship. Contrary to this finding, Kabeer (2005) study in south Asia revealed that microfinance has a vital contribution to women's economy but it does not automatically empower them.

Table 6. Hayes process macro result education as moderator

\begin{tabular}{|c|c|c|c|c|c|c|}
\hline \multicolumn{7}{|l|}{ Model } \\
\hline coeff & se & $\mathrm{t}$ & $p$ & \multicolumn{3}{|c|}{ LLCIULCI } \\
\hline constant & 377707.360 & 17216.917 & 21.938 & .000 & 343842.977 & 411571.743 \\
\hline microfin & 1.401 & .237 & 5.922 & .000 & .935 & 1.866 \\
\hline educatio & 7879.470 & 4647.290 & 1.695 & .091 & -1261.401 & 17020.341 \\
\hline Int 1 & .025 & .058 & .428 & .669 & -.090 & .140 \\
\hline
\end{tabular}

Creating a conducive environment for clients for income generation is one among different Amhara credit and saving institution activities. Through advice, the organization enables clients to spend the money on profitable business activities. 
From the study, it is clear that most clients' income increased from year to year. The microfinance industry played a significant role in enhancing the monthly income of female microfinance clients.

\section{Conclusion}

Access to microfinance institutions like credit, saving, and training helps women in economic development and decision making role on savings and credit and other business activities. Investing in women's economic development activities will dramatically improve for Ethiopian women's employment and other sections of society. From the study result, it is clear that microfinance has a significant impact on women's assets, income, saving, and control over the resource. Women microfinance clients have higher levels of income, better asset position, high saving amount, and better control over the resource in households and the surrounding community. Whatever is done to improve the microfinance service of credit provision and training will improve women entrepreneurship development.

The regressions result shows that the age of women, education, marital status, training, amount of credit, have a significant positive impact on women's economic empowerment. However, women's business experience has no significant impact on the economic development of women. Moreover, age and education have no moderation effect on the study.

\section{Limitations and Future Research Directions}

In this research, some limitations were identified. The study was limited to the Amhara credit and saving the institution of Ethiopia. Future research should include other microfinance working at the regional and national levels for better representation and generalizability. Moreover, this study investigates only age and education as moderator. The future study requires including other demographic variables such as marital status, number of the household as a moderator.

\section{References}

Addai, B. (2017). Women empowerment through microfinance: Empirical evidence from Ghana. Journal of finance and accounting, 5(I), I-II.

Alshebami, A. S., \& Khandare, D. M. (2015). The role of microfinance for empowerment of poor women in Yemen. International Journal of Social Work, 2(I), 36-44.

Belay, M., \& Amanpreet, S. (2019). Impact of microfinance through Amhara credit and saving institution on women's economic empowerment.International Journal of Recent Technology and Engineering, 8(4), 9696-9703.

Duflo, E. (2012). Women empowerment and economic development. Journal of Economic literature, 50(4), I05I-79.

Gundappa, M. (2014). Micro finance and Empowerment of Women: An Impact study of SHGS. Indian Streams Research Journal, 4(8).

Hayes, A. F. (2018). The Process macro for SPSS and SAS (version 3.0).

Hussain, J., Mahmood, S., \& Scott, J. (2019). Gender, microcredit and poverty alleviation in a developing country: The case of women entrepreneurs in Pakistan. Journal of International Development, 3I(3), 247-270.

Kabeer, N. (2005). Is microfinance a 'magic bullet' for women's empowerment? Analysis of findings from South Asia. Economic and Political weekly, 4709-4718.

Kato, M. P., \& Kratzer, J. (2013). Empowering women through microfinance: Evidence from Tanzania.

Khanday, M. I., Shah, B. A., Mir, P. A., \& Rasool, P. A. R. V. A. I. Z. (20I5). Empowerment of women in India-historical perspective. European Academic Research, 2(II), I4494-I4505.

Kaur, J. (2012). Microfinance and women empowerment: a study of Punjab.

Korkmaz, S., Goksuluk, D., \& Zararsiz, G. (20I4). MVN: An R package for assessing multivariate normality. The $R$ Journal, 6(2), I5I-I62.

Laha, A., \& Kuri, P. K. (20I4). Measuring the impact of microfinance on women empowerment: A cross country analysis with special reference to India. International Journal of Public Administration, 37(7), 397-408.

Ledgerwood, J. (1999). Sustainable banking with the poor. Microfinance Handbook. And Institutional and Financial Perspective.

Littlefield, E., Morduch, J., \& Hashemi, S. (2003). Is microfinance an effective strategy to reach the millennium development goals?. Focus note, 24(2003), I-II.

Mohapatra, S., \& Sahoo, B. K. (2016). Determinants of participation in self-help-groups (SHG) and its impact on women empowerment. Indian Growth and Development Review.

Naeem, A., Khan, S., ul Hassan, F. S., \& Muhammad, J. (2018).The Impacts of Microfinance on Women Entrepreneurs "A Case Study of District Quetta, Pakistan".

Odell, K. (2010). Measuring the impact of microfinance. Grameen Foundation, Washington, I-38.

Parveen, S., \& Leonhäuser, I. (2004). Empowerment of Rural Women in Bangladesh: A Household Level Analysis In: A Paper Presented in the conference on Rural Poverty Reduction through Research for the Development and Transformation. 5-7 October. Deutscher Tropentag-Berlin, German.

Parveen, S., \& Chaudhury, M. S. R. (2009). Micro-credit intervention and its effects on empowerment of rural women: the BRAC experience. Bangladesh Research Publication Journal, 2(3), 64I-647.

Ringkvist, J. (2013). Women's Empowerment through Microfinance: A case study on Burma.

Rahman, M. M., Khanam, R., \& Nghiem, S. (2017). The effects of microfinance on women's empowerment: new evidence from Bangladesh. International Joumal of Social Economics, 44(12), I745-I757. 
Rashid, F., John, M., Consolatta, N., \& Stephen, S. (2015). Impact of microfinance institutions on economic empowerment of women entrepreneurs in developing countries. International Journal of Management Science and Business Administration, I(I0), 45-55.

Rehman, H., Moazzam, A., \& Ansari, N. (2015). Role of microfinance institutions in women empowerment: A case study of Akhuwat, Pakistan. South Asian Studies, 30(I), I07-I25.

Rathiranee, Y., \& Semasinghe, D. M. (2015). Factors determining the women empowerment through microfinance: An empirical study in Sri Lanka. International Journal of Social, Behavioural, Educational, Economic, Business and Industrial Engineering, 9(5), 2328-2185.

Selvaraj, N. (2016). Impact of Micro-Credit on Economic Empowerment of Women in Madurai, Tamilnadu. Journal of Global Economics, 4(4).

Sell, M., \& Minot, N. (2018, November). What factors explain women's empowerment? Decision-making among smallscale farmers in Uganda. In Women's Studies International Forum (Vol. 7I, pp. 46-55). Pergamon.

Stewart, R., Van Rooyen, C., Dickson, K., Majoro, M., \& de Wet, T. (2010). What is the impact of microfinance on poor people?: a systematic review of evidence from sub-Saharan Africa.

Swapna, K. (2017). Impact of microfinance on women entrepreneurship. International Journal of Business Administration and Management, 7(I), 2278-3660.

Samad, M. A. (2014). Islamic micro finance: tool for economic stability and social change. Humanomics. https://doi.org/I0.I 108/H-I2-20I3-0085.

Sinha, F. (2006). Social rating and social performance reporting in microfinance. Towards a common framework, the SEEP network for the Argidius Foundation.

Tandon, T. (2016). Women empowerment: perspectives and views. The International Journal of Indian Psychology, 3(3), 6-12.

Wassie, S. B., Kusakari, H., \& Sumimoto, M. (2019). Performance of microfinance institutions in Ethiopia: Integrating financial and social metrics. Social Sciences, 8(4), II7.

Wanjiku, E., \& Njiru, A. (2016). Influence of microfinance services on economic empowerment of women in Olkalou constituency, Kenya. International Journal of Research in Business Management, 4(4), 67-78.

Yousuf, J., \& Dawit, T. (20I4). Women's Economic Empowerment Through Microcredit Intervention: The Case of Chinaksen Woreda, Oromiya National Regional State (Doctoral dissertation).

Copyrights

Copyright for this article is retained by the author(s), with first publication rights granted to the journal. This is an openaccess article distributed under the terms and conditions of the Creative Commons Attribution license (http://creativecommons.org/licenses/by/4.0/). 